\title{
The Function of Millennial Pendhapa Joglo in New Normal Era
}

\author{
Tri Prasetyo Utomo ${ }^{1,}$, Bani Sudardi ${ }^{2}$, Nanang Rizali Sardjono ${ }^{3}$, Wakit \\ Abdullah $^{4}$ \\ ${ }^{1,2,3,4}$ Faculty of Cultural Studies, Universitas Sebelas Maret, Surakarta, Indonesia \\ *Corresponding author. Email: triprasetyoutomo2263@gmail.com
}

\begin{abstract}
In The Traditional Javanese architecture, pendhapa often called front home and serves as a living room or public space. The discussion of pendhapa in this paper is more emphasis on function in the new normal era. Function of pendhapa have a characteristic. Pendhapa in this paper is traditional Javanese hall in the Javanese architecture. The generally of Pendhapa shaped Joglo, and is the only house that is owned by the noble persons. Joglo is in square a with four-poster as the main pillar. The four pillars support the roof towering in the middle. The main pillar in the Joglo house often called Saka Guru. The roof in the middle of Joglo house is called the roof Brunjung. Therefore, Pendhapa Joglo in the traditional Javanese architecture have a characteristic. Pendhapa initially serves as a gathering place and deliberation. Pendhapa in the place of social interaction between citizens and the people in the open society. Pendhapa often also called open room or public room. However, in its development Pendhapa Joglo can function as a social interaction of the development of the culture and social change in the new normal era.
\end{abstract}

Keywords: Pendhapa, function, and new normal

\section{INTRODUCTION}

Pendhapa Joglo in the Javanese architecture place of social interaction between citizens and the people in the new normal era. Joglo house of pendhapa often also called open room or public room before covid19 pandemic. Pendhapa generally formed Joglo, and is the only house that is owned by the noble persons. Joglo square and four-poster as the main pillar is often called Saka Guru. The four pillars support the roof towering in the middle is called the roof Brunjung. The slope of the roof is sharper than the pyramid roof. On development, pendhapa formed Joglo house has undergone many changes, so it has diverse forms and function. Here is some form of pendhapa Joglo: Pendhapa Joglo is building the house Traditional Javanese has the most complex formed. Basically pendhapa Joglo square four and only four-poster called saka Guru, so just a form of the middle courses of form Joglo house growing up now. Subsequent developments occur additions to parts of the skies so that the pules increases according to the needs. Pendhapa Joglo is a form of Javanese architecture that has full-loaded most ideal for use as a meeting room. Judging from the structure of the building, houses Joglo also has a more complete structure compared with other forms of Javanese architecture. Houses Joglo has a shape that is very flexible, because if you want to expand the space can be done simply by adding a porch around him, so that the poles and the structure became increasingly complete. Houses Joglo is a building that has a comprehensive plan space. Houses Joglo is used as pendhapa which serves as a meeting place and a place deliberation. So the Joglo house is only one form of various forms of Javanese architecture. Houses Joglo has a roof towering in the middle. which is referred to as the roof Brunjung. The roof is on the bottom is supported by four pillars called Saka Guru. Roofs Brunjung in Joglo house has the same shape on the sides facing each other, but in the frontrear side has a different shape to the left and rigbi side. On the irom-rear side of the trapezoid-shaped roof, while the left and right side of the triangular tapered top. Roofs Brunjung in house Joglo has a different shape when compared withbe roof Brunjung in house Limasan and Tajug house. Joglo house shape of the roof Brunjung higher and has a roof slope sharper flan the roof Brunjung in Limasan house, While the roof Brunjung in Tajug house has four equal sides are triangular shaped tapered top and have fee same inclination angle with the roof Brunjung in Joglo house.

In addition to the roof Brunjung, forms the roof Joglo has several different layers of roof slope angle between the shape of each other. In the second tier 
under the roof Brunjung is called the roofResponder with a slope angle of the sloping roof over the angle of the roof 'Brunjung'. In the third and fourth tier respectively called the roof Penitih and Peningrat. Both forms the roof of the same has a-more gentle shape of the roof compared to the slope of the roof responder and roof Brunjung. House roof shape Joglo has several types based on their shape and the number of types of the roof of which form twolayered, three-layered or four layers. The more layers in the form of the roof, the more complete and perfect form of Joglo house. Type houses of Joglo which has the form of a coated roof four houses Joglo the most perfect types, such as Houses Joglo Stoom damp and House Joglo Hageng. An example is Pendhapa Pura Mangkunegaran which is a type of house Joglo Hageng.

\section{FUNCTION OF JOGLO HOUSE IN THE PENDHAPA BEFORE COVID-19 PANDEMIC}

Joglo house of pendhapa was the home front that point to receive guests, breaks or other purposes, but not a place to stay (family bed). In generally, Joglo house of pendhapa always open meaning there was partitioned space before covid-19 pandemic. Home front or pendhapa must pamidangan beam with a length of rodents, reduced the number of number is a multiple of 5 (five) remain 2 (two). For example, beam 17 feet long, was reduced $3 \times 5=2$ feet; pemidangan rodents 12 feet minus $2 \times 5=2$ feet. All the numbers were reduced multiples of 5(five) remain 2 (two) called a 12-foot fell designation Kitri called home. Home fiont or pendhapa should measure falls Kitri. Joglo house of pendhapa is radiant cultural values of ethnic Javanese (Javanese Architecture). His is evident in its physical manifestation, such as the shape, the structure and the decoration. Joglo house of pendhapa physical form, ia addition to paying attention to the aesthetic values, are also bound by the cultural values prevailing in the Javanese community. Spatial systems always refer to the non-physical aspects that customs and beliefs that they profess. Therefore, Joglo house of pendhapa can blend with the natural environment and culture of the people. Uniqueness always appear on pendhapa, for example: the symmetrical shape of the building, roof shape and Lirnasan Joglo, has the main poles, has a lacade and a different side and facing south. Pendhapa is a building in the Java architecture located on the fiont. Joglo house of pendhapa building adjacent to Pringgitan and Griya Ageng. Pendhapa function is as a living room, interact with others, as well as a gathering place and deliberation. The shape and setting of the building that symbolizes pendhapa meaning of harmony between the occupants and the surrounding community.

Javanese cultural life in the city of Surakarta is a Javanese civilization rooted in the Kingdom. This civilization has a history of literature that has been there since four centuries ago, and has the art developed in the form of dance and sound art Kraton, and characterized by a religious life that is highly syncretistic, a mixture of elements of Hinduism, Buddhism, and Islam. This is especially true in the city of Surakarta, who developed into dozens of contemporary religious movement, called as movement psychotherapy. Regional palaces of Java are called Negarigung (Koentjaraningrat, 1984). Javanese culture centered on the Mataram Kingdom before it breaks into Kraton Surakarta. Given that in Central Java of yore is a cultural center that is the palace, the Surakarta in Bother discussion is considered to represent Central Java, it is based on the premise of the palace as a cultural center for the surrounding community. Culture that grew up in the surrounding regions, basically strongly influenced by the culture palace. Javanese way of life is inseparable from the role of King and power in the Kingdom. Given the position of the Palace as ths center of the universe, then setting the buildings within the palace cannot be separated from efforts to harmonize the Site of the king Kraton community with the universe. Position cannot be separated front the power authority has, also related to the spiritual concept which is presumably due to the influence of Indian center (Darsiti, 1989: 3). Traditional culture is BO longer a social states symbol, to anyone who could took away her economically, socially, and intellectually can be part of a noble culture. There is also a new pattern in the traditional art of professionalism. Apprenticeship in artistic inheritance pattern is replaced with the institutions of art. Formalism old palace of culture was replaced by formalism plural of the institutions of art (Kuntowijoyo, 1987).

Human life in the cultural environment of Java, basically stated on the basis of four areas or scope of the belief, that confidence, social, personal egression (personality) and problems or meaning. Thefour will affect the pattern of thought, action and his work. In terras of work, in which applies where the artificial environment or place of residence or work of architecture as part of the cultural life (Arya Ronald, 2005). The settlements in the urban concept of Java is an extension of the palace to the region Negari Dalem Agung. There are some of the terminology used to describe a place to stay. The concept of territory Dalem means a world where the family originated. Physically called dwelling or place of residence of the Javanese in Dalem terminology that 
is inside the fence where the house was buih. Omah own words human close to understanding the ancient Javanese language means the floor is livable. This means that in Javanese culture, the concept of the house was not referring solely to the physical building, but within the person and his family lived, $\mathrm{ft}$ is not permanent in the house may be closely associated with the idea of a place to stay as a home, not a building. Social cohesion which give a sense of security and territoriality pages recognized by the community as its Dalem is the main structure of the residential concept (Wiryomartono, 1995).

In the Javanese community, the arrangement of the house within a family consists of several houses. In addition to special homes for shelter (bed) family, no home of its own as Pendhapa for hearings or receive guests. Home to the family bed (Dalem) is called back home, while pendhapa called home front. Among the house back and front of the house there is a home interlace called Peringgitan derived from the word meaning Anggit Ringgit or puppet. The house is usually to hold puppet shows, while the audience sits in pendhapa or home front The house is one of culture. Cultural development of the past very nature centric, so that the house in the residential area or neighborhood (Kraton) family cannot be separated from the provision of the palace. The meaning of the provisions of the court does not mean the shape and structure of the house on their families and most people have to mimic the shape and composition of the court, even on the contrary, there is a ban mimic certain home arrangement Fibre (Kawruh Kalang, Pethikan Griya Jawi: 79). Java home building structure is an arrangement of spaces that reflect the distinctive buildings such as: pendhapa, pringgitan, dalem, pavvon, gandhok, and gadri. Relation between this arrangement is an arrangement of space / building process of its realization highly influenced by mythology and cosmology Java (Suhardi, 2004).

Joglo House manifestation is a manifestation of a way of trust, knowledge, ethics and aesthetics. Javanese, it is as the elaboration of the concept of the relationship between humans Java with its natural surroundings. Basically Javanese architecture consists of five kinds of shapes, and front views each have a symmetrical shape. The concept of building pendhapa more laid benchmark on nature, environment, people, culture and cosmology that they profess. Meanwhile, one very important factor in the design of buildings pendhapa is the scale and size of the building. The unit of measure used in Joglo house of pendhapa in different Javanese architecture with buildings pendhapa thriving today. Joglo house of pendhapa in Javanese architecture using a unit of measure that is derived from human limbs Java, such as asta (arm), tebah (width of the palm of the hand), kilan (the distance between the tip of the thumb to the little finger when the hand is stretched) and so forth. The use of human scale like this can produce works of building design is more reasonable and consistent with the physical needs of people's daily life of its inhabitants. Units in the Joglo house of pendhapa rather refers to the natural and human environment. In the design of Joglo house of pendhapa, appear to have the maturity of the design of integrating the elements of culture with aesthetic elements. The elements in question represents the union between the transcendental element of trust in the context of cosmology. Thus there are elements that are contrary to the concepts of trust, such as the look of the building, the direction / orientation of the building, the architecture, system layout and the structure and construction of the building. View from the front view and a side view of the building, seen (hat it shows kesetangkupan Building Java (symmetry) on each. Meanwhile, when building Java viewed from the front it can be recognized by their kiwa section (left) and section tengen (right), kiwa section is part of the building which is located on the left side direction toward the occupant, as docs tengen section (right). Both pans are no different from those commonly known as a side of the building, as is the case with ngajeng parts (front and part wingking (rear) which has elements similar construction. In other words, part-wingking ngajeng buildings, many associated with the direction of building Java pamanjang; while part-tengen kiwa associated with panyelak direction. (Josef Prijoiomo. 1995: 25).

Joglo house of pendhapa rectangular-shaped floor plan and has the main pillars in the middle of the room. In its development, pendhapa experiencing widening by adding pillars supporting its edges in accordance with the needs of the space. In addition, the expansion pendhapa also done by expanding toward the four sides to form a lobby called overhang. Therefore, pendhapa can be used as a meeting room or space where deliberation among citizens in the surrounding community. In the development of the cultural community, pendhapa also functioned as a commercial space. In the present values developed in the community more diverse and open (open society).

In such societies, diversity of values caused by the growing needs of an increasingly diverse members of society as well [26]. The values of a diverse society provide an opportunity to the changing values of Javanese culture. Likewise, functionality and value Joglo house of pendhapa that developed in diverse and open society like this are likely to undergo change and development. Therefore, based on the development needs of the community at the present time, there is also a change 
in the function and value Joglo house of pendhapa in Javanese architecture.

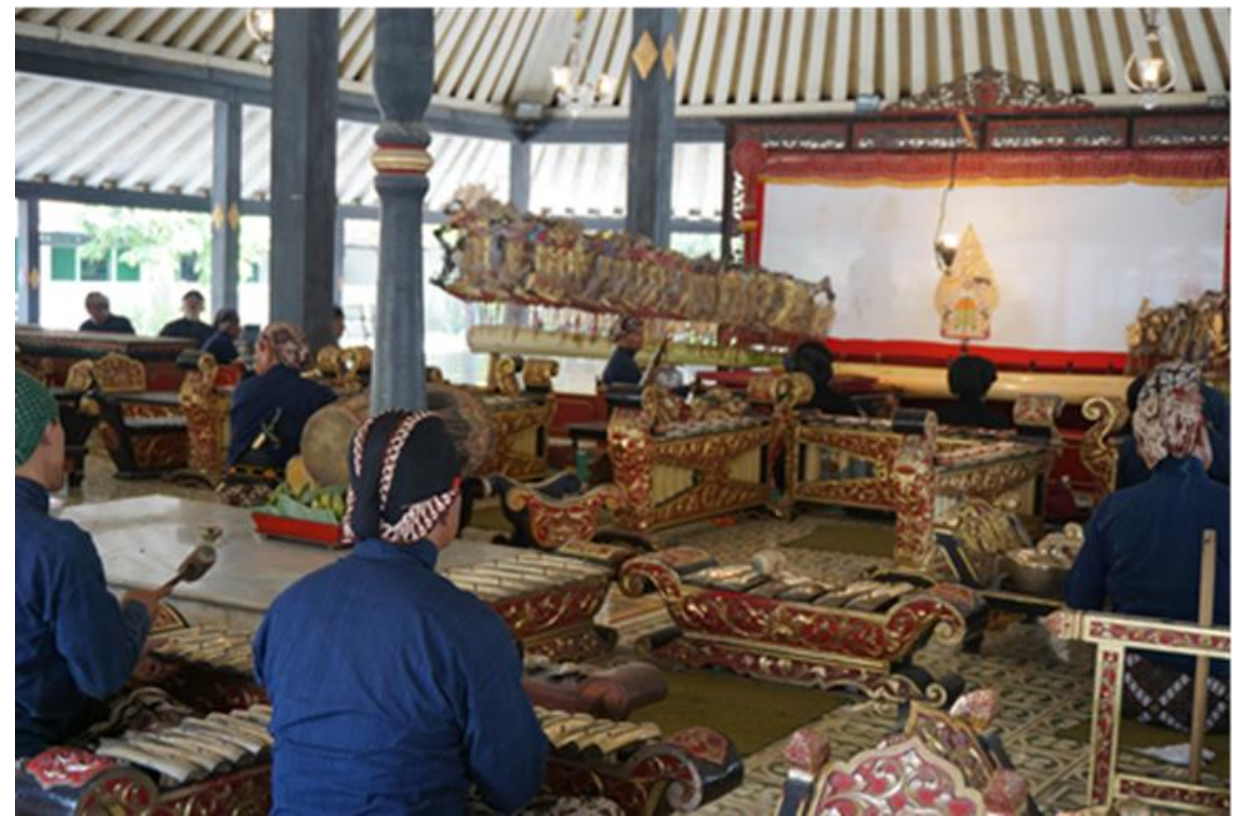

Figure 1 Joglo House of Pendhapa in Javanese Architecture before Covid-19 pandemic

\section{FUNCTION CHANGESIN THE JOGLO HOUSE OF PENDHAPA DURING COVID-19 PANDEMIC}

Javanese Architecture is determined by the culture and attitude of the human life of Java. Therefore, in the embodiment. Joglo house of pendhapa Javanese architecture is a home that reflects the welfare of the world. In principle Joglo house of pendhapa Javanese architecture is a house that refers so the environment, the religious environment, family environment and socio-cultural environment. This is because the Javanese architecture moved from the concept of tradition that exists is that the human being is one the element of natural world, so humans should fee united with God. Man cannot be separated from nature, man must unite with nature, and human beings must also be united with his Lord. Thus, the purpose of life is to follow nature, enhance and maintain the natural realm to the welfare of the world. Javanese architecture consists of a wide variety of physical forms architectural, among others: Joglo, Tajug, Limasan, kampung and Panggang-Pe, Joglo is one of the few forms of Javanese architecture. Joglo has a different shape and form the most perfect among other forms of Javanese architecture. Compared with other Java area, the form Joglo growing in the region of Surakarta has a specific character. In terms of the shape and structure of the building. Joglo is a building has a high value concept, in most of Javanese community, Joglo building functioned as Pendhapa. Physical form Joglo as building pendhapa, in addition to paying attention to the aesthetic values, are also bound by the cultural values prevailing in the Java community, such as the system layout always refers to the nonphysical aspects that customs and beliefs that they profess. Therefore, Joglo as pendhapa buildings can blend with the natural environment and culture of the people. Uniqueness always appear on the building Joglo, as well as symmetrical shapes that symbolize balance awl all farmal-an, roof towering malambangtan charismatic nature and the authority, has four Saka Guru who symbolizes strength or robustness and power, have a look-fece different side-rear symbolizes less open attitude and a southfeeing building that symbolizes the populist (protector of the little people). Most traditional buildings, has charts arrangements which are oflen based on things that are holy or sacred, because religion and ritual is the center. This is because the traditional view of society is religious (Rapopot, 1979; Wondoamiseno, 1991). Similarly, the traditional houses of Indonesia cannot be separated from the values of sanctity and also often has value as a type or symbol. For example, Javanese architecture, the symbol of the sanctity centered in the middle senthong (krobongan/pasren/petanen), homage is addressed to Dewi Sri as a protective 
emblem of fertility or a bride who will forward the human generations. Dewi Sri denoted as rice seeds to be planted back in. While the statue Loro blonyo generally placed in front of this symbol Krobongan. By expected, the occupants will get a sense of ease and happy in her house. Thus, a sense of ease and happy in the house one of the background purposes Javanese life. Besides home symmetrical shape or alignment represents the balance to be achieved in life. In Traditional Javanese house, pendhapa often called front home and serves as a living room. Pendhapa often also called open room or public room. However, in its development Pendhapa can function as a social communication space or can also called as a social communication media. It is associated with the development of the culture and lifestyle of the people in the open society.

In the Java community, spatial concepts in Java Architect consists of several spatial arrangements. Besides Griya Ageng/Dalem, as a family residence, there is also a front room called Pandhapa which serves as a reception room. The space serves as a femiiy room called griya ageng/dalem or omah mburi (back home\}, while the space used as a living room or pendhapacalled omah ngarep (front of house). Among the house back and front of the house there is space interface called pringgitan. Pringgitan word comes from the word ringgit means puppet. Pringgitan generally serves as a venue for staging puppet. Puppet audience directly in pendhapa is space generally consists of men. While the Wayang shadow can be seen from space dalem is usually done by women.

Javanese cultural life in the city of Surakarta is a Javanese civilization rooted in the Kingdom. This civilization has a history of literature that has been there since four centuries ago, and has the art developed in the form of dance and sound art Kraton, and marked if a religious life that is highly syncretistic, a mixture of elements of Hinduism, Buddhism, and Islam. This is especially true in the city of Kraton Surakarta, where growing dozens of contemporary religious movement, called the movement psychotherapy. Regional palaces of Java are called Negarigung (Koentjaraningrat, 1984). Javanese way of life cannot be separated by the King's role and power in the palace. Given the position of the palace as the center of the universe, then setting the buildings within the palace cannot be separated from efforts to harmonize the king's palace to the community life of the universe it. Position King cannot be separated from the power of the authorities, to do it is with spiritual concepts that may be due to cultural influence from India (Darsiti, 1989). Traditional culture is no longer a social status symbol, to anyone who could took away her economically, socially, and intellectually can be part of high culture. There are also new patterns of professionalism to the traditional arts. Apprenticeship in artistic inheritance pattern is replaced with the institutions of art. Formalism old palace of culture was replaced by formalism plural of the institutions of art (Kuntowijoyo, 1987).

Java community is not a collection of individual human beings connecting with one another as well as individual the one with lie community, but a unity that bound between each other by the norms of life based religion. The tradition as well as a community foundation that is mutual cooperation. The system of family life in Java reflected in customary law. As the smallest unit society is the family life. A family can live together in the community to create the life of the most little known village communities. Several hundred villages which are geographically incorporated in an area, such as Surakarta, turns each have a social life norms are different. Therefore, people who live in these areas is a family community called regional community (Herusatoto, 1991). 


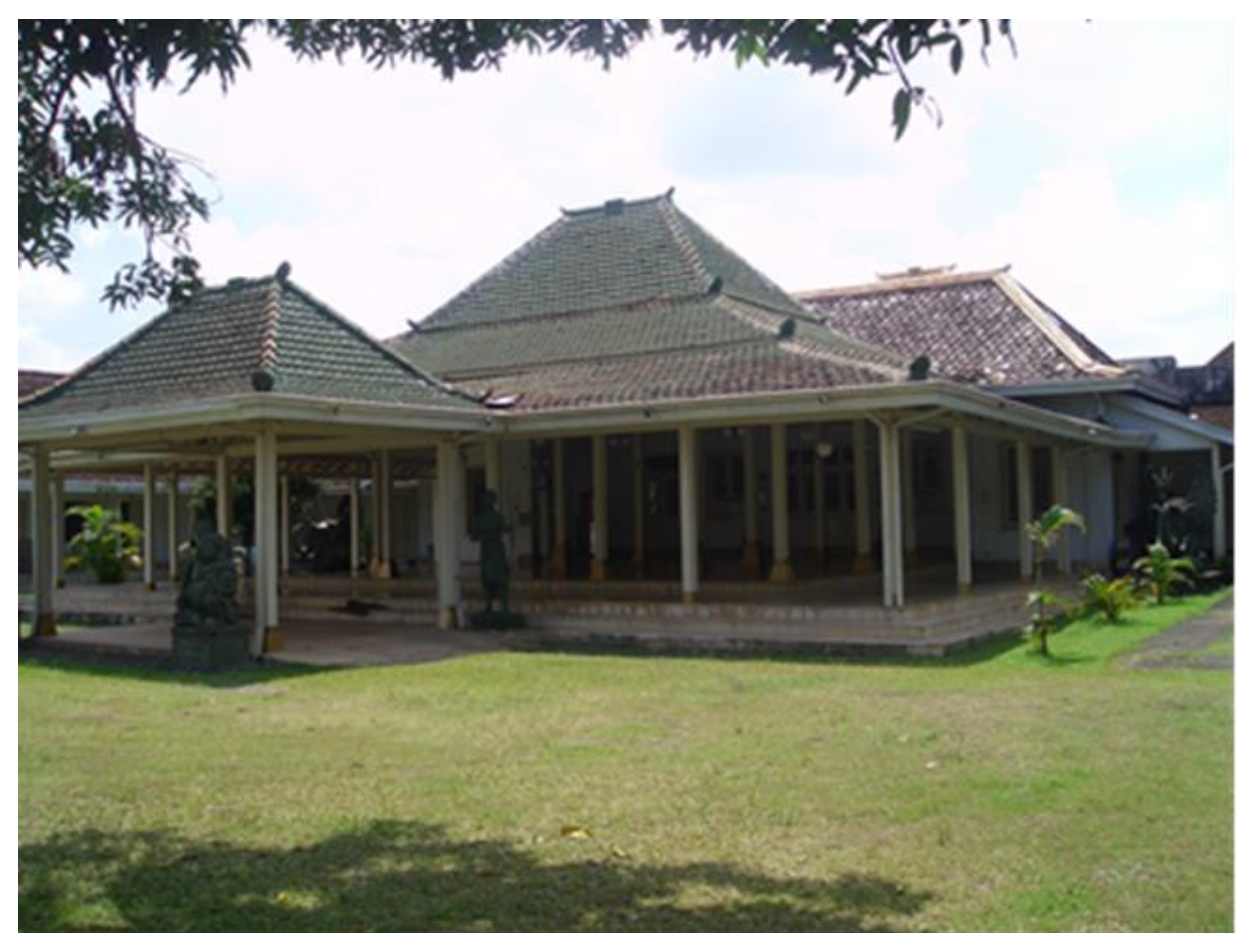

Figure 2. Joglo House of Pendhapa in Javanese Architecture during Covid-19 pandemic.

\section{CONCLUSION}

Based on the description of the changes function of Joglo house of pendhapa. The authors can conclude the following: Javanese community in Surakarta is the Javanese community that has a view of life which cannot be separated by the king's role and power in Kraton. Pendhapa growing in Sarakarta, most have the characteristic form of Joglo. House of Joglo square form and has four main pillars called Saka Guru. The four pillars support the roof towering in the middle, and the roof is called roof Branjung. Joglo house of Pendhapa serves as a gathering place, deliberation and social interaction between citizens before covid-19 pandemic. While in development, function Joglo house of pendhapa shifted into do not a public space during covid-19 pandemic. Joglo house of Pendhapa cannot function as a social communication space and social interaction during covid-19 pandemic.

\section{REFERENCES}

[1] Budhisantoso, S, 1984, Identitas Budaya dalam Karya Arsitektur, Simposium arsitektur, Jakarta.

[2] Budihardjo, Eko, 1997, Arsitek dan Arsitektur Indonesia: Menyongsong Masa Depan, ANDI, Yogyakarta.
[3] Budihardjo, Eko, 1997, Arsitektur sebagai Warisan Budaya, Penerbit Djambatan, Jakarta.

[4] Carey, Peter, 1986, Ekologi Kebudayaan Jawa \& Kitab Kedung Kebo, Pustaka Azet, Jakarta.

[5] Geertz, C, 1960, The Religion of Java, The University of Chicago Press, USA.

[6] Hamzuri, Rumah Tradisional Jawa, Proyek Pengembangan Permuseuman DKI Jakarta.

[7] Herusatoto, Budiono, 1991, Simbolisme dalam Budaya Jawa, PT. Hanindita, Yogyakarta.

[8] Ismunandar, 1987, Joglo: Arsitektur Rumah Tradisional Jawa, Dahara Prize, Semarang.

[9] Jencks, Charles, 1973, Modern Movements in Architecture, Anchor Books, Garden City, New York.

[10] Koentjaraningrat,1984, Kebudayaan Jawa, Penerbit Balai Pustaka, Jakarta.

[11] Koentjaraningrat, 1987, Kebudayaan Mentalitas dan Pembangunan, PT. Gramedia, Jakarta.

[12] Koentjaraningrat, 1993, Manusia dan Kebudayaan Di Indonesia, Djambatan, Jakarta. 
[13] Kuntowijoyo, 1987, Budaya dan Masyarakat, PT. Tiara Wacana, Yogyakarta.

[14] Lombard, Denys, 1996, Nusa Jawa; Silang Budaya, PT. Gramedia Pustaka Utama, Jakarta.

[15] Magnis, Franz \& Suseno, 1985, Etika Jawa: Sebuah Analisis Falsafi tentang Kebijaksanaan Hidup Jawa, PT. Gramedia, Jakarta.

[16] Mangunwijaya, YB, 1988, Wastu Citra: Pengantar ke Ilmu Budaya Bentuk Arsitektur, Sendi-sendi Filsafatnya beserta Contoh-contoh Praktis, PT. Gramedia, Jakarta.

[17] Muhadjir, Noeng, 2000, Metodologi Penelitian Kualitatif, Penerbit Rake Sarasin, Yogyakarta.

[18] Mulder, Niels, 1996, Pribadi Masyarakat Jawa, Pustaka Sinar Harapan, Jakarta.

[19] Prijotomo, Josef, !992, Ideas and Forms of Javanese Architecture, Gajah Mada University Press, Yogyakarta.

[20] Prijotomo, Josef, 1995, Petungan: Sistem Ukuran dalam Arsitektur Jawa, Gajah Mada University Press, Yogyakarta.

[21] Ronald, Arya, 1990, Ciri-ciri Karya Budaya Di Balik Tabir Keagungan Rumah Jawa, Universitas Atma Jaya, Yogyakarta.

[22] Snyder, James C \& Catanese, Anthony J, 1979, Introduction to Architecture, McGraw-Hill Book Company, New York.

[23] Vidler, Anthony, 1976, The Third Typology, Oppisitions, MIT Press.

[24] Wiryomartono, A. Bagoes P. 1995. Seni Bangunan dan Seni Bina Kota Di Indonesia, PT. Gramedia Pustaka Utama, Jakarta.

[25] Wittkower, 1973, Architecture Principles in The Age of Humanism, Academi Edition, London.

[26] Raza, S.H., Bakar, H.A. \& Mohamad, B. 2018. Advertising appeals and Malaysian culture norms: Scale content validation, Journal of Asian Pacific Communication 28 (1), 61-82 